\title{
PROTESTOS DO SUPREMO TRIBUNAL FEDERAL NA PRIMEIRA REPÚBLICA - O JULGAMENTO DO HABEAS CORPUS 8800 E O CONFLITO ENTRE OS PODERES JUDICIÁRIO E EXECUTIVO
}

\author{
PROTESTS BY THE SUPREME COURT DURING THE FIRST REPUBLIC - THE \\ TRIAL OF HABEAS CORPUS 8800 AND THE CONFLICT BETWEEN EXECUTIVE \\ AND JUDICIARY POWERS
}

Laila Maia Galvão*

RESUMO: a presente pesquisa investiga, a partir de uma análise institucional, a atuação do Supremo Tribunal Federal (STF) durante a Primeira República, com foco especialmente na relação tensa estabelecida entre os Poderes Executivo e Judiciário. Serão apresentados alguns episódios envolvendo a chamada edição de protestos, em que o Tribunal se manifestava por meio de uma nota pública contra as ações do Poder Executivo. A partir da análise mais detalhada de um desses episódios, ocorrido em 1923, buscar-se-á identificar como se dava esta disputa por espaços de poder entre o STF e a Presidência da República.

PALAVRAS-CHAVE: Primeira República. Protesto. Supremo Tribunal Federal.

ABSTRACT: This research investigates the role of the Brazilian Supreme Federal Court (Supremo Tribunal Federal - STF) during the First Republic (1889-1930) from an institutional perspective, focusing especially on the conflictual relationship between the executive power and the judiciary one. It describes some episodes involving the so-called issue of protests in which that Court expressed its resentment through a public statement against the actions of the executive branch. From the detailed analysis of one of these episodes, occurred in 1923, it will be possible to demonstrate the competition for power between the Supreme Court and the Presidency.

KEYWORDS: Brazilian Supreme Federal Court. First Republic. Protest.

\section{INTRODUÇÃO}

Para compreender o papel desempenhado pelo Supremo Tribunal Federal (STF) na Primeira República é fundamental empreender análise não só normativa, mas também institucional, de suas decisões, com especial atenção para a disputa entre os poderes Executivo e Judiciário. Para tanto, aprofunda-se o estudo de alguns episódios que foram ainda pouco explorados pela historiografia, mas que podem trazer indícios sobre a postura do Tribunal diante de certos conflitos. Tais episódios compartilham o seguinte roteiro: o descumprimento de alguma decisão do STF por parte do Executivo e uma tentativa do

\footnotetext{
* Graduada em Direito pela Universidade de Brasília (2010) e mestre em Direito pela Universidade Federal de Santa Catarina (2013). Atualmente é doutoranda em Direito pela Universidade de Brasília. Tem experiência na área de Direito, com ênfase em Direito Constitucional e História do Direito.E-mail: lailamg@gmail.com Revista da Faculdade de Direito - UFPR, Curitiba, vol. 60, n. 1, jan./abr. 2015, p. 61-84.
} 
Tribunal de esboçar uma reação, muitas vezes por meio da elaboração de uma nota de protesto. O debate entre os ministros do STF a respeito dessas manifestações de repúdio e sobre a conveniência ou não de publicá-las são úteis para a reconstrução do pano de fundo das decisões políticas tomadas pela Instituição.

$\mathrm{Na}$ primeira parte do artigo, há uma breve incursão pela obra de alguns pesquisadores que estudaram o funcionamento do Supremo Tribunal Federal na Primeira República e suas respectivas chaves interpretativas. Já na segunda parte são apresentados alguns casos do STF, com destaque para o julgamento do habeas corpus 8800 e o debate no Tribunal sobre a conveniência da publicação de uma espécie de moção de repúdio contra um ato do então presidente da República, Arthur Bernardes. A escolha de um caso específico se justifica pela necessidade de se demonstrar em mais detalhes o trâmite desse tipo de discussão no STF.

\section{INTERPRETAÇÕES SOBRE O STF NA PRIMEIRA REPÚBLICA}

Uma das obras mais significativas sobre a história do Supremo Tribunal Federal é, sem dúvida, o conjunto de quatro livros redigidos por Lêda Boechat Rodrigues $(1965,1968$, 1991 e 2002), sendo três deles sobre o período da Primeira República. A autora trabalhou por vários anos no próprio Supremo Tribunal Federal $^{1}$ e, inspirada nos trabalhos históricos realizados sobre a Suprema Corte dos $\mathrm{EUA}^{2}$, decidiu realizar semelhante empreitada a respeito da mais alta corte brasileira. Trata-se de obra de fôlego, que primou por uma abordagem mais historiográfica e analítica, em vez da abordagem mais próxima da crônica que prevalecia até então. A obra de Lêda Boechat sobre a história do Tribunal se mantém como importante referência para o estudo do Poder Judiciário na Primeira República.

\footnotetext{
${ }^{1}$ Lêda Boechat Rodrigues trabalhou desde jovem e até a aposentadoria no STF, tendo a oportunidade de estabelecer amizades com alguns dos ministros da casa. Sem dúvida, esse vínculo afetivo com o Tribunal, cuja história se mistura com sua própria, pode ser observado em sua escrita. A própria autora o explicita no quarto volume de sua obra: "Do entusiasmo inicial que senti por esta Casa nasceu, com o tempo, o meu amor pelo STF e o desejo de retratá-lo. Esse amor pelo Supremo Tribunal Federal e pela Suprema Corte dos Estados Unidos começou cedo. Em 17 de novembro de 1936, com 18 anos e tendo já terminado o terceiro ano da Faculdade Nacional de Direito da Universidade do Brasil, fui nomeada taquígrafa do Supremo Tribunal Federal, aprovada em concurso público de provas e títulos" (RODRIGUES, 2002, p. 23).

${ }^{2}$ Lêda Boechat Rodrigues morou, durante os anos de 1943 e 1944, nos Estados Unidos, quando seu marido, o historiador José Honório Rodrigues, ganhou bolsa de pesquisa da Fundação Rockfeller (RODRIGUES, 1958, p. 7). Em seus livros, é recorrente a articulação entre a história do STF e a da Suprema Corte estadunidense: “Com a transplantação, para o Brasil, do regime federativo e do princípio da supremacia do poder Judiciário, pela prerrogativa a este concedida de declarar a inconstitucionalidade das leis e dos atos do Executivo, nasce e floresce em terras brasileiras o prestígio incomparável da mais típica e original das instituições americanas: a Corte Suprema dos Estados Unidos" (RODRIGUES, 1958, p. 11).

Revista da Faculdade de Direito - UFPR, Curitiba, vol. 60, n. 1, jan./abr. 2015, p. 61-84.
} 
Os três livros de Lêda Boechat apresentam, de modo geral, um tom elogioso à atuação do Tribunal durante a Primeira República. A autora estabelece a seguinte divisão cronológica: os anos de 1891 a 1898 abrangeriam a "defesa das liberdades civis" por parte do STF; os anos de 1899 a 1910 figurariam como um momento de "defesa do federalismo" e, entre 1910 e 1926, haveria a elaboração mais consciente de uma "doutrina brasileira do habeas corpus". A linha condutora da narrativa da autora consiste em apontar os feitos positivos da Corte nesse período, mesmo a contragosto dos outros Poderes, e de relativizar decisões mais problemáticas ${ }^{3}$.

Vale destacar a conjuntura política do País no momento em que Lêda Boechat Rodrigues publicava seus livros e sua dedicação ao resgate da história daquela instituição. No prefácio do tomo I, de 1965, a autora mencionou os ataques que o Tribunal estaria sofrendo após o Golpe de 1964 e traçou uma analogia com os movimentos, nos EUA, contra a Suprema Corte e a atuação do Justice Warren ${ }^{4}$. Não é improvável que a repulsa às intervenções que o STF sofrera na Primeira República refletissem também sua postura crítica diante das investidas da Ditadura Militar contra a independência do STF.

No tomo III, publicado já em 1991, Lêda Boechat Rodrigues afirmou que, diante das violências praticadas pelo Poder Executivo ou seus delegados contra as liberdades individuais, o STF teria visto à sua frente apenas um caminho: "ampliar o habeas corpus através da interpretação lata ou construction do texto constitucional, art. $72 \S 22$, na visão liberal que dele teve, em primeiro lugar, como grande advogado e excelso constitucionalista, Rui Barbosa” (RODRIGUES, 1991, p. 32-3). Segundo a autora, essa prática de ampliar a abrangência do habeas corpus para proteger garantias individuais passou a ser denominada "doutrina brasileira do habeas corpus", a qual seria, em sua opinião, "a maior criação jurisprudencial brasileira" (RODRIGUES, 1991, p. 17).

Portanto, os livros enaltecem a atuação do Tribunal, colocam a doutrina brasileira do habeas corpus no patamar mais elevado da originalidade jurídica e destacam o exercício do

\footnotetext{
${ }^{3}$ Diz Lêda Boechat: “Assim, mesmo quando a nossa mais alta Corte não tomou o melhor caminho, houve vozes vencidas que afirmaram os corretos princípios democráticos e merecem, pela sua forma e conteúdo, ser incorporadas, ao lado de alguns pronunciamentos unânimes ou da maioria, à tradição cultural brasileira" (RODRIGUES, 1968, p. 11).

4 "Mas como a sua irmã do Norte, a Corte Suprema dos Estados Unidos, sofreu o Supremo Tribunal Federal desde os seus anos iniciais, e está sofrendo principalmente hoje, as maiores pressões políticas: lá, há anos, é raro o dia em que elementos reacionários e da extrema direita não pedem o impeachment de seu grande Presidente, o Chief Justice Earl Warren, e aqui, a partir do Movimento de Abril, o Supremo Tribunal Federal tem estado permanentemente na alça de mira da chamada 'linha dura' militar, sendo bravamente defendido pelo seu atual Presidente, Ministro Ribeiro da Costa” (RODRIGUES, 1965, v. I, p. 3). 
controle de constitucionalidade ${ }^{5}$. São raras as exceções em que, por exemplo, a autora critica a falta de quorum nas sessões (RODRIGUES, 1968, p. 8). Lêda Boechat se coloca, explicitamente, contra a famosa frase de João Mangabeira (apud RODRIGUES, 1991, p. 38), que disse ter sido o STF o Poder que mais falhou na República ${ }^{6}$.

Certo viés otimista sobre a atuação do STF na Primeira República, especialmente no que toca à utilização dos habeas corpus, também pode ser encontrado na pesquisa de Gladys Sabina Ribeiro sobre cidadania e luta por direitos na Primeira República. Ao contrário de Lêda Boechat, que parte de uma análise endógena e autorreferencial da atuação do Tribunal, Gladys Sabina dá destaque a uma história vinda de baixo, a partir da análise de processos propostos por populares. A pesquisa demonstra que o STF acolhia pleitos da população não apenas reativos, mas também propositivos (RIBEIRO, 2009, p. 101). Também exalta a utilização alargada do habeas corpus que, nas palavras da autora, "funcionava como uma espécie de atalho usado pela população para chegar à democracia” (RIBEIRO, 2009, p. 115). Sobre a relação estabelecida entre o STF e o Poder Executivo, destaca que o Tribunal, assim como os demais Poderes, estava inserido em um projeto comum de modernização. No entanto, em busca de um espaço próprio de atuação, o STF teria contestado decisões e pedidos do Executivo (RIBEIRO, 2009, p. 101).

Andrei Koerner (2010) desenvolveu pesquisa a respeito da atuação do STF, mas com perspectiva bastante distinta da de Lêda Boechat, alcançando resultados completamente diversos. Ele parte da hipótese de que as características institucionais do Poder Judiciário federal durante a Primeira República foram determinadas pelas características mais gerais do sistema político federal (KOERNER, 2010, p. 171). Koerner argumenta que o controle do Poder Judiciário federal detinha certa importância política naquele período, uma vez que o Judiciário federal era competente para apreciar conflitos entre a União e os estados, crimes políticos, etc.

Apesar de reconhecer a relevância do Tribunal no período, Koerner avalia em sua pesquisa como se dava a interlocução desse Poder com os demais e como o STF se inseria nas disputas políticas. Essa abordagem, talvez menos preocupada com uma narrativa que colocasse o Tribunal como defensor das garantias individuais, e mais atenta às tomadas de

\footnotetext{
5 "Foi definitivamente incorporada entre as atribuições do Poder Judiciário em todos os seus graus, a de exercer o controle de constitucionalidade das leis e dos atos administrativos, em face de casos concretos" (Ibid., p. 144). 6 "É claro que o Supremo Tribunal Federal teve altos e baixos. Não fôra ele instituição humana, em que é impossível a perfeição. Repito que me parece muito infeliz a frase de João Mangabeira de que o Supremo Tribunal foi o Poder que mais falhou na República. Provavelmente estava João Mangabeira, quando disse isso, no mundo da Lua" (RODRIGUES, 1991, p. 38). 
decisão mais pragmáticas de seus ministros, de acordo com seus interesses políticos, acarretou um olhar diferente para a atuação do Tribunal na Primeira República.

Koerner defende que a vitaliciedade do cargo de ministro do STF fazia com que o Tribunal ficasse menos à mercê das mudanças das oligarquias dominantes no poder. Assim, nem sempre se podia prever o resultado de um julgamento e, se o julgamento estivesse em desacordo com a vontade da situação, ficava em risco o cumprimento adequado da decisão final do Tribunal ${ }^{7}$.

Em estudo sobre os habeas corpus referentes a conflitos eleitorais entre oligarquias estaduais no período de 1908 a 1911, testou-se como é que o STF teria escapado ao forte “esquema de aliança entre o Executivo e o Legislativo federais e entre o nível federal e o nível estadual do poder", quando vigorava a política dos governadores (KOERNER, 2010, p. 4567). A partir da pesquisa de alguns desses casos entre 1908 e 1911, Koerner identificou que:

[...] nos conflitos entre as oligarquias estaduais analisados, os votos dos ministros do STF acompanharam as posições dos chefes políticos aos quais eles eram ligados. Os casos apresentados nos dão uma indicação de que os votos dos ministros do STF nos demais casos políticos deviam variar do mesmo modo (KOERNER, 2010, p. 192).

Portanto, para Koerner, as votações no STF seguiam a lógica dos grupos oligárquicos da política dos governadores. A pesquisa, de forma original, lançou luz sobre a atuação política dos ministros do STF levando em consideração a disputa entre as oligarquias de seus estados de origem.

Perspectiva também interessante, por meio de uma análise institucional a respeito da atuação do Supremo Tribunal Federal na Primeira República, pode ser encontrada no trabalho de Maria Fernandes Salcedo Repolês $(2007,2010)$. Utilizando como chave de leitura a ideia de "identidade do sujeito constitucional", trabalhada originalmente por Michel Rosenfeld (2003), ela reconstrói o papel institucional de guardião da constituição na história brasileira.

O papel de guardião da constituição teria sido desempenhado pelo Poder Moderador no Brasil Império, passando para a responsabilidade do STF na Primeira República. No Brasil Império, a identidade do sujeito constitucional, que deveria ser um lugar vazio, foi apropriada pelo Imperador: "ao reconstruir o papel institucional do guardião máximo da Constituição, vemos a sua tendência a se apropriar dos espaços de definição de identidade que deveriam ser

\footnotetext{
7 "Em virtude da vitaliciedade do cargo de ministro do STF, a maioria do Tribunal não correspondia sempre à aliança que dominava a política federal. Desse modo, havia alguma incerteza sobre o resultado das decisões do tribunal, o que conduzia a complicadas negociações entre ministros e chefes políticos, e também a pressões destes sobre o tribunal, colocando em dúvida sua real obediência às decisões judiciárias que lhes fossem desfavoráveis" (KOERNER, 2010, p. 173).

Revista da Faculdade de Direito - UFPR, Curitiba, vol. 60, n. 1, jan./abr. 2015, p. 61-84.
} 
mantidos vazios"8. A passagem do papel de guardião do Poder Moderador, exercido pelo Imperador, para um órgão de cúpula, no caso, o STF, teria representado, na visão da autora, um ganho evolutivo ${ }^{9}$. Mais do que uma análise linear, a autora demonstra como esse processo se deu por meio de sucessos e fracassos.

Por fim, cabe mencionar o livro O Supremo Tribunal Federal e a construção da cidadania, de Emília Viotti da Costa (2001). No prefácio dessa obra, a autora afirmou que nos debates contemporâneos sobre democracia apenas os poderes Legislativo e Executivo seriam mencionados, com raras referências ao Judiciário. Isso a teria levado a rever a história daquela que seria a principal instituição do Judiciário brasileiro: o Supremo Tribunal Federal. A autora reproduz uma análise otimista à atuação do Tribunal, perseguindo a contribuição dessa instituição para a construção da cidadania no Brasil.

Já retomando a atuação do STF na Primeira República: o Tribunal teria como funções primordiais: (i) decidir a constitucionalidade dos atos dos demais Poderes; (ii) julgar litígios entre os estados e a União e (iii) defender, na qualidade de última instância, os direitos dos cidadãos (COSTA, 2007, p. 29). A pesquisadora apresenta, então, a tese de que o STF teria funcionado como uma "caixa de ressonância" nesse período. Assim, num País com sucessivos golpes de estado e com um Poder Executivo que governaria por decreto, declararia estado de sítio, e que se recusaria a obedecer decisões da mais alta Corte de Justiça:

[...] é de se esperar que esta [Corte de Justiça] funcione como uma caixa de ressonância que registra os ritmos agitados da história nacional. Sendo inevitavelmente levado a participar das lutas políticas que se travam à sua volta e sofrendo suas consequências, o STF é ao mesmo tempo agente e paciente dessa história (COSTA, 2007, p. 29).

Em determinados momentos, Emília Viotti destacou o caráter político das decisões do Tribunal, pelas vinculações dos próprios ministros ${ }^{10}$. No entanto, o foco principal do relato

\footnotetext{
${ }^{8}$ Cf. REPOLÊS, 2007, p. 5. Ainda sobre o Poder Moderador como guardião da constituição: “A análise do exercício da guarda máxima da Constituição pelo critério político do Poder Moderador nos revela os riscos inerentes a esse modelo de controle que aparecem principalmente na permanente necessidade de personificação e de busca de uma figura carismática capaz de por si só sustentar a simbologia da autoridade, necessária à tarefa de legitimar as decisões políticas que ajudam a definir a identidade constitucional" (ibid., loc. cit.).

9 “Assim, a República opera um deslocamento fundamental: o exercício da autoridade e o exercício do poder não se situam no mesmo nível, a autoridade, assumida nesses casos pelo Supremo Tribunal Federal, limita-se a estabelecer e garantir as condições fixas e não revogáveis, para o exercício do poder político democrático, que, por definição, deve permanecer aberto" (REPOLÊS, 2007, p. 15).

10 "O viés político das decisões transparecia nos casos de habeas corpus ou nos de conflitos entre as oligarquias estaduais por ocasião das eleições, quando os ministros tinham que decidir entre as facções que lutavam pelo poder ou arbitrar nos embates entre União e Estados. Criaturas da patronagem que presidia as carreiras políticas do Império, dificilmente os ministros escapavam das malhas das lealdades que haviam forjado ao longo da vida. O Supremo Tribunal politizava-se" (COSTA, 2007, p. 35-6). Chega inclusive a citar Andrei Koerner ao mencionar vinculação entre ministros e chefes locais (COSTA, 2007, p. 60). Cita também a jurisprudência mais Revista da Faculdade de Direito - UFPR, Curitiba, vol. 60, n. 1, jan./abr. 2015, p. 61-84.
} 
cronológico dos afazeres do STF na Primeira República seguirá a chave de leitura da "caixa de ressonância", dando destaque aos embates entre o Tribunal e os poderes Executivo e Legislativo $^{11}$.

A abordagem de Emília Viotti, a partir da figura da caixa de ressonância, é interessante no sentido de dar destaque às relações estabelecidas entre os Poderes. Não obstante, pode passar a impressão de um posicionamento mais passivo que ativo do STF diante dos acontecimentos políticos, o que nem sempre se verifica nas fontes. É possível enxergar esta relação tensa do STF com os outros Poderes como jogo de avanços e recuos, a depender do contexto político, muitas vezes com o intuito de fortalecer uma instituição recente e frágil.

A hipótese aqui aventada é de que havia nesse período uma disputa por espaços de poder e o STF avançava e recuava a depender da conjuntura política. Se essa conjuntura eralhe favorável, o Tribunal se arriscava um pouco mais, ocupando mais espaços de poder. Se não era, recuava.

Acredita-se que essa perspectiva de compreensão da atuação do Tribunal, em vez de substituir importantes análises feitas por Lêda Boechat, Andrei Koerner, Gladys Sabina, Maria Repolês e Emília Viotti da Costa, visa acima de tudo a construir essa história a partir de outros elementos, contribuindo com as análises já desenvolvidas.

\section{HABEAS CORPUS 8800}

Uma análise da atuação do Supremo Tribunal Federal ao longo dos quase quarenta anos de vigência da Constituição de 1891 evidencia períodos de maior e menor independência do Tribunal em relação ao Poder Executivo. O então recém-criado Tribunal, instância

abrangente em casos de concessão de habeas corpus, o que é chamado por alguns de teoria brasileira do habeas corpus, aproximando-se, nesse ponto, dos escritos de Lêda Boechat Rodrigues (COSTA, 2007, p. 37).

${ }^{11}$ A autora dá destaque ao famoso caso em que Floriano Peixoto teria ameaçado os ministros do STF. As prisões realizadas por Floriano Peixoto durante o estado de sítio de 1892 fizeram com que Rui Barbosa impetrasse habeas corpus em favor dos presos. Atribui-se a Floriano Peixoto a seguinte frase: "se os juízes do Tribunal concederem o habeas-corpus aos políticos, eu não sei quem amanhã lhes dará o habeas-corpus de que, por sua vez, necessitarão". Não se sabe ao certo se Floriano Peixoto proferiu ou não essa frase. Diz Emília Viotti: "Verdadeira ou não, a ameaça retratava fielmente a disposição do presidente. Talvez por isso os ministros tenham negado por dez votos contra um o habeas corpus tão brilhantemente defendido por Rui Barbosa diante do público que lotava a sala das sessões." Rui Barbosa afirmou que competia ao Tribunal defender a liberdade pessoal contra as invasões do Executivo. Mas a maioria dos Ministros entendeu que o Poder Judiciário não tinha competência para apreciar o caso antes da decisão do Congresso, a quem cabia aprovar ou desaprovar o estado de sítio declarado pelo presidente. $O$ voto vencido do ministro Pisa e Almeida "argumentava que a suspensão das garantias constitucionais por tempo indeterminado era uma violência e o remédio contra ela era o habeas corpus". Em 1898, o STF inverteria sua decisão e adotaria a doutrina defendida por Rui Barbosa seis anos antes (COSTA, 2007, p. 38).

Revista da Faculdade de Direito - UFPR, Curitiba, vol. 60, n. 1, jan./abr. 2015, p. 61-84. 
superior do Poder Judiciário federal, tinha de se estruturar e buscar se fortalecer como instituição. A depender da conjuntura, o Tribunal demonstrava revolta ou resignação diante do descumprimento de uma de suas decisões por parte do Poder Executivo. Para melhor compreender esses momentos de crise, examinaremos abaixo o julgamento do habeas corpus 8800 .

\subsection{RESUMO DO CASO}

Um importante caso julgado pelo STF na Primeira República foi o habeas corpus 8800, de dezembro de 1922. Tratava-se, como era comum, de um caso envolvendo duplicatas de assembleias legislativas. No Estado do Rio de Janeiro havia dois grupos políticos que disputavam o poder. Um deles, liderado por Nilo Peçanha, tinha como candidato à presidência do Estado o advogado Raul Fernandes. O outro apresentava como candidato o militar Feliciano Sodré. Nas eleições, o grupo ligado a Nilo Peçanha ganhou tanto as eleições para as cadeiras na assembleia legislativa como para a presidência do Estado.

O grupo rival, inconformado com esse resultado, protocolou protesto ao juiz federal Leon Roussoulières e formou outra assembleia legislativa, a qual foi mantida em funcionamento por seis meses. Com a posse marcada para o dia 31 de dezembro, Raul Fernandes temia que o outro grupo, por meio da assembleia recém-criada, empossasse Feliciano Sodré com o apoio do governo federal e do então Presidente da República, Arthur Bernardes.

A partir desse receio, os advogados Levi Carneiro e Assis Chateaubriand impetraram habeas corpus no Supremo Tribunal Federal para garantir a posse de Raul Fernandes no dia 31 de dezembro de 1922. O STF era o último recurso a ser buscado, caso a demanda fosse contra os interesses do governo federal.

A ordem de habeas corpus foi concedida a Raul Fernandes por uma maioria apertada de seis votos a cinco. Votaram contra a concessão da ordem os seguintes ministros: Geminiano da Franca, Edmundo Lins, Pedro dos Santos, Godofredo Cunha e Viveiros de Castro. Votaram a favor: Guimarães Natal, que foi o relator do processo, Hermenegildo de Barros, Alfredo Pinto, Leoni Ramos, Pedro Mibielli e André Cavalcanti ${ }^{12}$.

\footnotetext{
${ }^{12}$ Em carta de João Luiz Alves, então secretário de finanças do governo de Minas Gerais, a Arthur Bernardes, datada de 24 de junho de 1922, havia uma série de especulações sobre outro habeas corpus no STF. A carta dizia o seguinte: "Habeas corpus: tem-se feito tudo (confidencial). O Azeredo conseguiu e garantiu o voto do Viveiros - que, como se sabe, é contrário aos habeas corpus políticos. A estatística última é esta: - pelo habeas corpus: certos o Leoni, o Lacerda e o Mibielli; duvidosos - mas suspeitos - o Hermenegildo e o Natal (5); - contra o habeas corpus: o André, Alfredo Pinto, Pedro Santos, Edmundo Lins, Moniz Barreto, Godofredo, Viveiros (7). Revista da Faculdade de Direito - UFPR, Curitiba, vol. 60, n. 1, jan./abr. 2015, p. 61-84.
} 


\subsection{OS PRIMEIROS DIAS DE JANEIRO DE 1923: ENTRE A POSSE E A INTERVENÇÃO FEDERAL}

Após a decisão do STF no habeas corpus 8800, no dia 29 de dezembro de 1922, o Presidente do STF, Hermínio Espírito Santo, remeteu ofício ao juiz federal no Estado do Rio de Janeiro, Leon Roussoulières, para que fosse cumprida determinação do referido acórdão, referente à concessão da ordem para que Raul Fernandes e Arthur Leandro de Araújo Costa tomassem posse sem sofrer quaisquer constrangimentos.

Raul Fernandes foi empossado normalmente no dia 31 de dezembro. No entanto, Feliciano Sodré também foi empossado na mesma data e, nos primeiros dias de janeiro, havia uma confusão geral no estado fluminense, com deposições nas prefeituras e conflito intenso em várias cidades. Não se sabia qual era o governo legítimo.

Em nove de janeiro de 1923, Raul Fernandes enviou mensagem ao relator do habeas corpus 8800, ministro Guimarães Natal, relatando a situação. Contou que sua posse ocorrera normalmente e que enviara mensagem ao Presidente da República agradecendo a segurança prestada, mas que teve "a surpresa de receber, em resposta, a comunicação de haver sido também empossado no mesmo cargo o Major Feliciano Pires de Abreu Sodré, acrescentando que desses fatos ia dar conhecimento ao Congresso Nacional"13.

Raul Fernandes, ao expor a situação caótica do Estado do Rio de Janeiro naquele momento e o posicionamento dúbio de Arthur Bernardes, afirmou ao relator do processo, Guimarães Natal, que o Presidente da República fomentava a formação de duplicatas e determinava que autoridades federais não se correspondessem com funcionários estaduais. Segundo Fernandes, a interrupção das relações com a União dificultava a atuação do novo governo. A representação buscou detalhar a forma como o governo federal reprimia a ação do

[...]" (ALVES, 1922). João Luiz Alves ainda afirmava que a oposição, por meio de J. J. Seabra, tentava convencer André Cavalcanti a votar de outro modo, remetendo-lhe uma carta do cardeal. A partir dessa carta já é possível perceber certa divisão do Tribunal, que se repetiria em 1923, e também o posicionamento não confirmado de André Cavalcanti.

${ }^{13} \mathrm{O}$ inteiro teor da petição enviada por Raul Fernandes ao relator do processo, Guimarães Natal, está presente no O JORNAL de 11 de janeiro de 1923.

Revista da Faculdade de Direito - UFPR, Curitiba, vol. 60, n. 1, jan./abr. 2015, p. 61-84. 
novo governo estadual de oposição, relatando os casos de deposição de prefeitos e vereadores nas cidades do interior ${ }^{14}$.

A estratégia de se recorrer ao Judiciário e, em especial, ao STF, mais parecia um apelo ao último recurso que restava para seguir à frente do cargo de presidente do Estado. Uma vez que o grupo político de Raul Fernandes não detinha apoio do governo federal e, consequentemente, perdia apoio de suas forças policiais ${ }^{15}$, a última opção era argumentar juridicamente e obter apoio da polícia por meio da imposição do Poder Judiciário.

Em 10 de janeiro de 1923, o juiz federal enviou ofício ao Presidente do STF relatando os últimos acontecimentos no Estado. De acordo com o juiz, a posse teria sido efetuada normalmente na sede do Tribunal de Relação do Estado, no Palácio da Justiça, com o auxílio de tropa do $2^{\circ}$ Batalhão de Caçadores, colocado à disposição pelo Ministro de Guerra. O juiz justificou que o acórdão havia sido devidamente cumprido, uma vez que houve a cerimônia de posse ${ }^{16}$. No entanto, o juiz Roussoulières relatou no ofício os fatos que se sucederam à posse, denunciando a duplicata de autoridades executivas e os conflitos pelo interior. Ao mesmo tempo que o juiz buscava explicar sua atuação ampliada no caso, eximiase da responsabilidade quando indicava que a determinação do acórdão fora cumprida. Em primeiro lugar, o juiz federal narrou como havia providenciado, com auxílio da intervenção da força federal, a manutenção no exercício dos respectivos cargos dos funcionários arrecadadores estaduais em alguns municípios, por meio de uma "ampla interpretação dos efeitos da sentença que se executava"17. Depois, ao narrar as deposições nas câmaras municipais, argumentou que "não sendo as câmaras municipais e os prefeitos delegados do poder estadual", escapavam à "proteção do habeas corpus concedido".

O juiz encerrou o ofício dizendo que as providências relativas ao acórdão foram tomadas e que tiveram "realização inteira", mas aproveitou para reafirmar o caos em que se encontrava o Estado e clamava por novas medidas: "tudo constitui lamentável dissenção a comprometer as instituições republicanas e o bom nome do país, reclamando prontas medidas

\footnotetext{
${ }^{14}$ A ajuda do governo federal se dava por meio do envio de agentes de polícia do Distrito Federal para o Estado do Rio de Janeiro: "Foram despachados para vários municípios do interior agentes e praças da polícia do Distrito Federal, que, coniventes com os políticos oposicionistas, procederam à deposição das autoridades locais" (Representação de Raul Fernandes transcrita no O JORNAL, 11 de janeiro de 1923).

${ }^{15}$ Na representação, Raul Fernandes relatou também que foram detidos, por ordem do chefe de polícia do Distrito Federal, três sargentos e dois oficiais, segundo ele, "dos mais bravos e dedicados ao Governo". No mesmo dia a prisão foi relaxada sem que houvesse sido realizado interrogatório. Levaram de volta apenas o seguinte aviso: "a polícia em Niterói já se revoltara" (BRASIL, 1923, p. 1041).

${ }_{16}$ Ofício do Juiz Seccional ao Ministro Espírito Santo (O JORNAL, 11 de janeiro de 1923).

${ }^{17}$ Tais municípios eram: S. Fidelis, Cambuci, Friburgo, Capivari, Araruama, Rio Bonito e Barra do Piraí. De acordo com o ofício do juiz federal, houve solicitações de apoio da força federal em outros pontos do território fluminense e todas elas foram atendidas (Ofício do Juiz Seccional ao Ministro Espírito Santo. O JORNAL, 11 de janeiro de 1923)
}

Revista da Faculdade de Direito - UFPR, Curitiba, vol. 60, n. 1, jan./abr. 2015, p. 61-84. 
asseguradoras da normalidade". Provavelmente instruído por Arthur Bernardes, Roussoulières abria espaço para uma interpretação de que o Estado do Rio de Janeiro passava por "comoção intestina".

Nesse caso, é fundamental compreender a atuação do juiz federal Leon Roussoulières, que ficou responsável pela execução da decisão daquele Tribunal. As idas e vindas da atuação do juiz demonstravam a falta de independência do magistrado e o jogo da influência política envolvendo o Presidente da República e políticos locais. Roussoulières era diretamente ligado a Arthur Bernardes, tendo colaborado ativamente em sua campanha presidencial de $1922^{18}$.

O Presidente do STF, ministro Hermínio Francisco do Espírito Santo, remeteu ofício em resposta ao juiz federal Leon Roussoulières. $\mathrm{O}$ ministro Presidente do STF entendia que o acórdão não estava sendo respeitado e exigia que o juiz federal tomasse as providências necessárias para manter Raul Fernandes no cargo ${ }^{19}$.

Não obstante, nova mensagem foi remetida ao juiz Roussoulières pelo Presidente do STF, por meio do telegrama 10.824, em que o presidente do STF afirmava ter se convencido de que o habeas corpus fora devidamente cumprido ${ }^{20}$. Nesse episódio fica demonstrado que o

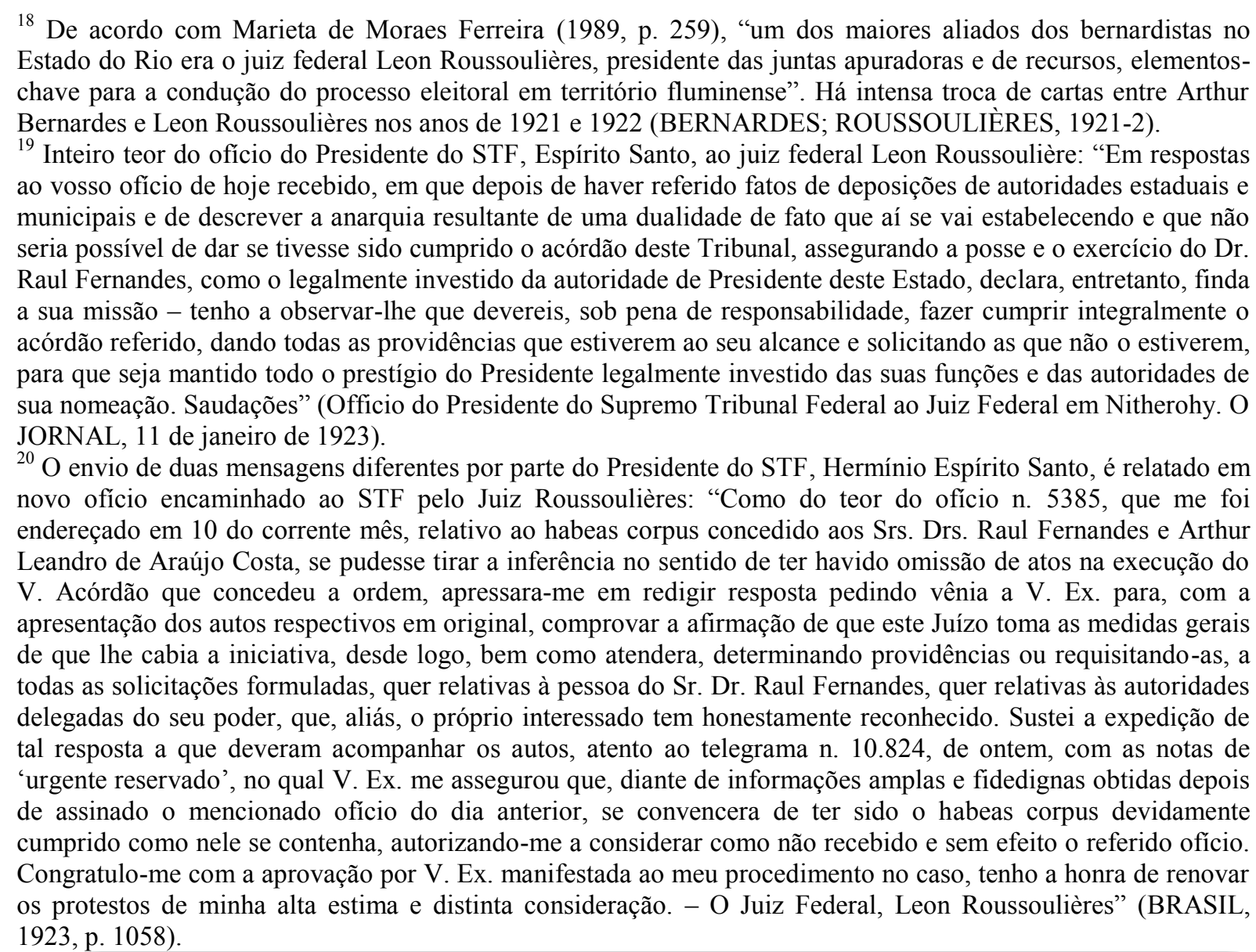

Revista da Faculdade de Direito - UFPR, Curitiba, vol. 60, n. 1, jan./abr. 2015, p. 61-84. 
Presidente do STF, de um dia para o outro, mudou de opinião e passou a entender que a decisão do STF havia sido devidamente cumprida, usando como justificativa o recebimento "de informações amplas e fidedignas obtidas depois de assinado o mencionado ofício do dia anterior".

É provável que o Presidente do STF, Hermínio do Espírito Santo, tenha sofrido pressões por parte de Arthur Bernardes para mudar de opinião. Segundo o ministro Hermenegildo de Barros, o Presidente do STF teria ido ao Palácio do Catete em reunião com o Presidente da República, e então, "melhor informado dos fatos ocorridos oficiou ao Juiz Federal revogando o ofício anterior e dando por cumprido o habeas corpus"21.

Se a versão de Hermenegildo de Barros estava correta, torna-se evidente o papel dúbio desempenhado pelo STF no período. Em um primeiro momento, o presidente da instituição, ministro Espírito Santo, quis firmar a autoridade da decisão no HC 8800, exigindo que o juiz federal Roussoulières se utilizasse de todos os instrumentos possíveis para executar o acórdão. $\mathrm{O}$ tom da mensagem era rígido, inclusive ameaçando responsabilizar o juiz federal pelo possível descumprimento da decisão. O presidente do STF não fraquejou na hora de cobrar o estrito cumprimento do acórdão.

Em um segundo momento, teria se reunido com o Presidente da República no Palácio do Catete. Logo em seguida, enviou novo ofício dizendo que o habeas corpus havia sido cumprido, uma vez que Raul Fernandes tomara posse. Talvez, percebendo as ações que seriam tomadas pelo Poder Executivo federal, o Presidente do STF tenha decidido alterar sua posição para que não se tornasse explícita a sobreposição do Poder Executivo ao Poder Judiciário. Para Arthur Bernardes, seria negativo ser acusado de ter descumprido acórdão do STF e, por isso, a declaração de que o acórdão fora cumprido deixava-o livre para agir da forma como quisesse dali em diante.

Em pronunciamento posterior, o ministro Guimarães Natal argumentou que o ministro Espírito Santo e o Presidente Arthur Bernardes tinham negociado uma saída que não atingisse demasiadamente a imagem de nenhum dos Poderes que representavam ${ }^{22}$. O ministro

\footnotetext{
${ }^{21}$ Manifestação de Hermenegildo de Barros na sessão secreta do STF do dia 13 de janeiro de 1923: “Ora, o Ministro Procurador-Geral tem competência para denunciar o juiz seccional que o Presidente do Supremo Tribunal já considera incurso em responsabilidade, por não ter dado execução à ordem de habeas corpus. Pouco importa que tendo o Presidente do Tribunal estado no Palácio do Catete em conferência com o Presidente da República, e então melhor informado dos fatos ocorridos houvesse oficiado ao juiz federal revogando seu ofício anterior e dando por cumprido o habeas corpus, uma vez que ao Presidente do Supremo Tribunal falecia competência para tomar por si só tão importante deliberação. Em suma, o habeas corpus não foi cumprido, tanto que se acha destituído de suas funções o Dr. Raul Fernandes, a quem o Supremo Tribunal garantiu o exercício das mesmas funções" (CORREIO DA MANHÃ, 18 de janeiro de 1923, p. 1).

${ }^{22}$ Essa negociação prevendo uma saída que não ferisse a imagem de nenhum dos Poderes estava implícita em declaração de Guimarães Natal na sessão de 17 de janeiro de 1923. Ele mencionou o episódio da revogação do Revista da Faculdade de Direito - UFPR, Curitiba, vol. 60, n. 1, jan./abr. 2015, p. 61-84.
} 
Guimarães Natal afirmou que, em nome da harmonia entre os Poderes, tinham sacrificado a independência do Judiciário.

\subsection{SESSÃO SECRETA DE 13 DE JANEIRO DE 1923}

No dia 10 de janeiro de 1923, Arthur Bernardes, com o auxílio de João Luiz Alves e do jurista Aurelino Leal, publicou o Decreto 15922 determinando a intervenção federal no Estado do Rio de Janeiro. Havia um reforço da argumentação de que o habeas corpus fora devidamente cumprido. A argumentação principal do Decreto se referia à dualidade de poderes no estado fluminense ${ }^{23}$.

A sessão do Supremo Tribunal Federal do dia 13 de janeiro de 1923 seria tomada pela discussão sobre qual seria a postura do Tribunal diante da intervenção federal e do suposto descumprimento da decisão do habeas corpus $8800^{24}$. A sessão do STF para discutir o caso estava cheia, com a presença de políticos, advogados, jornalistas ${ }^{25}$ e curiosos. O Procurador-Geral da República, Pires e Albuquerque, abriu a sessão lendo as informações prestadas pelo Ministro da Justiça, João Luiz Alves ${ }^{26}$. A partir do gesto de enviar essas informações à sessão do Supremo, fica evidente que o Ministro da Justiça era o agente do

ofício por parte do Presidente do STF: "V. Ex., Sr. Presidente, zeloso pelas prerrogativas do Tribunal, cujas decisões não poderiam ficar em sua execução, ao sabor das conveniências políticas ou entregues ao achincalhe dos burladores, dirigiu logo um ofício ao juiz federal ordenando-lhe que, sob pena de responsabilidade, desse integral execução ao acórdão. Era a mais elementar das providências a tomar no caso, mas o gesto enérgico de V. Ex. poderia obrigar o Juiz Federal a revelar a verdadeira causa da inexecução do acórdão, e essa revelação acarretaria talvez um conflito de poderes de difícil solução. Diante de tão tenebrosa consequência posta ante os olhos de V. Ex. por conselheiros avisados e prudentes deliberou V. E. reconsiderar o seu primeiro ofício ao Juiz Federal e dar por integralmente cumprido [...] o acórdão. [...] Triunfou a sofistaria, invocando a necessidade de se salvar o princípio da harmonia dos poderes, custasse embora o sacrifício da independência do Judiciário e a virtual abolição do regime federativo, base da organização da República" (CORREIO DA MANHÃ, 18 de janeiro de 1923, p. 1).

23 “'.... Considerando que o Poder Executivo federal, em obediência à decisão judicial, satisfez a requisição da força federal precisa para empossar o impetrante, garantindo-lhe o exercício do cargo, tendo sido o habeas corpus devidamente cumprido, conforme comunicação oficial do juiz federal da seção do Rio de Janeiro [...] Resolve intervir, na forma do art. $6^{\circ}$, n. 3 combinado com o n. 2 do mesmo artigo da Constituição da República, no Estado do Rio de Janeiro, nomeado interventor por parte do Governo da União o Dr. Aurelino de Araujo Leal [...]" (BRASIL, 1923).

${ }^{24} \mathrm{O}$ ministro Guimarães Natal, relator do habeas corpus 8800, ao receber a reclamação de Raul Fernandes, encaminhou-a ao Procurador-Geral da República para que este elaborasse seu parecer. A sessão do STF, portanto, formalmente retomava a discussão a respeito dessa reclamação.

${ }^{25}$ Reportagem do Jornal do Commercio de 14 de janeiro de 1923: "O Supremo Tribunal Federal apresentava ontem, por ocasião da abertura da sua sessão ordinária, um aspecto desusado, só verificado por ocasião dos grandes julgamentos que ali se realizam. Efetivamente pouco depois do meio-dia era grande o número de advogados, políticos e pessoas interessadas na decisão que o tribunal deveria tomar em face dos últimos acontecimentos do Estado do Rio de Janeiro. Todas as dependências do recinto estavam repletas e a custo se conseguia um lugar". No Correio da Manhã: "Vinte minutos antes de 1 hora da tarde, com as galerias da elevada Corte repletas e os corredores entupidos de curiosos, o presidente Hermínio do Espírito Santo anunciou que ia abrir a sessão" (CORREIO DA MANHÃ, 14 de janeiro de 1923, p. 3).

${ }^{26} \mathrm{O}$ inteiro teor do documento elaborado por João Luiz Alves pode ser encontrado na edição do jornal O Paiz, de 14 de janeiro de 1923, à página cinco.

Revista da Faculdade de Direito - UFPR, Curitiba, vol. 60, n. 1, jan./abr. 2015, p. 61-84. 
governo responsável por tentar eliminar as rusgas surgidas entre os Poderes Judiciário e Executivo $^{27}$.

Em linhas gerais, o Ministro confirmou a informação de que o habeas corpus fora devidamente cumprido e ressaltou que o Poder Executivo fez tudo o que estava ao seu alcance $^{28}$, eximindo o Presidente da República e o próprio Ministério da Justiça de qualquer responsabilidade $^{29}$. Em momento algum, portanto, o Poder Executivo reconheceu ter descumprido a ordem de habeas corpus do Tribunal. A intervenção no Estado do Rio, na argumentação elaborada pelo Executivo, ocorreu após a posse de Raul Fernandes, quando a ordem de habeas corpus já havia sido devidamente executada. Segundo João Luiz Alves, a intervenção federal, decorrente da desordem política no interior do Estado, não significava uma afronta ao STF: "O decreto de intervenção e as instruções ao interventor esclarecem a intervenção e os propósitos do governo, sem a menor quebra de seu acatamento ao Egrégio Tribunal e da harmonia dos poderes constitucionais" (Jornal O PAIZ, 14 de janeiro de 1923, p. 5).

O Presidente do STF, ministro Espírito Santo, comunicou que a primeira parte da sessão seria secreta, para discutir a reclamação de Raul Fernandes sobre o descumprimento da decisão do habeas corpus 8800. O ministro Hermenegildo de Barros argumentou sobre a importância de manter a sessão pública, por envolver fatos públicos e notórios. A questão foi encaminhada à votação. Votaram a favor da realização de sessão pública: ministros Hermenegildo de Barros, Godofredo Cunha e Guimarães Natal. Votaram a favor da realização de sessão secreta os ministros Geminiano da Franca, Alfredo Pinto, Viveiros de Castro, Leoni Ramos, André Cavalcanti e Pedro dos Santos ${ }^{30}$.

\footnotetext{
${ }^{27}$ Nessa intermediação entre o Presidente da República e o Presidente do STF, o então Ministro da Justiça, João Luiz Alves, desempenhou importante papel. João Luiz Alves, antes de ocupar o Ministério, havia sido secretário de finanças do governo estadual de Artur Bernardes. Em 1924, ele viria a ocupar a vaga de ministro do STF deixada pelo falecimento de Espírito Santo (RODRIGUES, 1994, p. 399).

28 "O Poder Executivo fez tudo quanto devia, no uso de suas atribuições, para que fosse cumprida a ordem de habeas corpus, porque tudo a que era obrigado consistia em por, para isso, a necessária força à disposição do Juiz" (O PAIZ, 14 de janeiro de 1923, p. 5).

29 "O Estado de notória anarquia, promovido por massas populares, em consequência da dualidade funcional de governos, anarquia reconhecida pelo reclamante e confirmada pelo Juiz Federal, no seu ofício, ao colendo Tribunal, lido na última sessão, não pode ser levado à culpa do governo, que não praticou ou mandou praticar ato algum para provocá-lo ou alimentá-lo" (ibid., loc. cit.).

30 De acordo com a reportagem do Jornal do Commercio, Pedro dos Santos teria declarado votar pela sessão secreta porque o Presidente do STF declarara haver motivos graves para que assim fizesse (JORNAL DO COMMERCIO, 14 de janeiro de 1923).
}

Revista da Faculdade de Direito - UFPR, Curitiba, vol. 60, n. 1, jan./abr. 2015, p. 61-84. 
A sessão, portanto, foi declarada secreta. Alguns jornais publicaram resumos do que teria acontecido na sessão ${ }^{31}$. A ata da sessão secreta seria lida e aprovada na sessão seguinte do STF e publicada no jornal Correio da Manhã do dia 18 de janeiro.

De acordo com a ata, o relator do habeas corpus 8800, Guimarães Natal, descreveu que foi fomentada a dualidade de assembleias, e que souberam disso por comunicação do juiz federal e por exposição documentada dirigida por Raul Fernandes. O ministro Guimarães Natal, inconformado com o decreto determinando a intervenção federal, apresentou aos colegas ministros um protesto contra o "desacato ao HC 8800 pelo Decreto 15922", que, segundo ele, representava o "maior atentado à autoridade de uma decisão judicial",32. A proposta de Guimarães Natal era publicar na imprensa um protesto reafirmando a decisão do Tribunal e exigindo seu imediato cumprimento.

Em seguida, o ministro Hermenegildo de Barros, que também havia votado pela concessão da ordem a Raul Fernandes, afirmou que não tinha dúvidas de que o acórdão fora “solenemente desrespeitado" (CORREIO DA MANHÃ, 18 de janeiro de 1923, p. 1) e que, portanto, subscreveria de pronto a proposta de Guimarães Natal. No entanto, disse que preferia forma mais breve de protesto, lançando sugestão própria. $O$ protesto de Hermenegildo de Barros possuía um tom muito forte e fazia sérias acusações ao Poder Executivo, afirmando que o decreto de intervenção 15922 seria "inexistente" ${ }^{33}$. As duas

\footnotetext{
${ }^{31}$ Os jornais governistas, o Jornal do Commercio e O Paiz, expuseram no dia 14 de janeiro relato muito semelhante sobre o que teria ocorrido na sessão secreta do STF do dia anterior. Já os jornais O Jornal e Correio da Manhã, também no dia 14, apresentaram informações diferentes sobre o assunto.

32 Inteiro teor do protesto produzido por Guimarães Natal: "O Supremo Tribunal Federal, único juiz da sua competência, porque o é da competência dos outros dois poderes políticos, quando julga-lhe os atos arguidos de exorbitantes de suas atribuições constitucionais, tendo conhecimento do decreto n. 15922, de 10 do corrente, pelo qual o Executivo Federal, com manifesta violação do art. $6^{\circ}$ da Constituição da República, deliberou intervir no Estado do Rio de Janeiro, não para assegurar a execução do acórdão 8800, de 27 de novembro de 1922, que garantiu ao Dr. Raul Fernandes o direito de, livre de qualquer constrangimento, tomar posse do cargo de Presidente do Estado e de exercer as respectivas funções de acordo com a constituição e leis estaduais, isto é, pelo período e pelo modo nelas estabelecidos, mas formalmente para desacatá-lo no essencial, que era o exercício do cargo; não para manter a forma republicana federativa, mas para deturpá-la, arbitrariamente, fomentando por seus agentes uma dualidade de poderes, de fato, porque, de direito, seria impossível constituir-se ela no Estado conforme o demonstrou o dito acórdão; não para restabelecer a ordem e a tranquilidade no Estado; à requisição do respectivo governo, mas para, independente de qualquer requisição, perturbá-los, invadindo o território do Estado com seus agentes, acompanhados de força federal e de polícia desta capital e depondo autoridades estaduais e municipais constituídas, como resulta com a mais clara evidência da comunicação do juiz federal e da exposição documentada dirigida pelo Dr. Raul Fernandes ao relator do acórdão; tendo conhecimento daquele decreto que representa o maior atentado à autoridade de uma decisão judicial, que nenhum outro poder tem competência para rever e alterar, e o mais profundo golpe na constituição e no regime republicano federativo, que a decisão desacatada preserva, contra ela protesta e declara que mantém seu julgado integralmente para que produza todos os efeitos, que por direito dele decorram, e determina que seja esse protesto transcrito na ata da sessão de hoje, sendo esta publicada na imprensa" (CORREIO DA MANHÃ, 18 de janeiro de 1923, p. 1).

${ }^{33}$ Sugestão de protesto elaborada por Hermenegildo de Barros: "O Supremo Tribunal Federal acaba de receber comunicação de haver o Presidente da República decretado a intervenção no Estado do Rio de Janeiro e nomeado um interventor em substituição ao Dr. Raul Fernandes, que ali se achava no exercício das funções de Revista da Faculdade de Direito - UFPR, Curitiba, vol. 60, n. 1, jan./abr. 2015, p. 61-84.
} 
propostas de protesto, por sua vez, afirmavam que o Poder Executivo passara por cima da decisão do STF e que isso feria a separação dos poderes.

Passou-se à discussão do protesto apresentado por Guimarães Natal. O primeiro voto favorável ao protesto foi do ministro Alfredo Pinto ${ }^{34}$, que afirmou votar assim porque seria "coerente com a atitude que assumiu como advogado e em pleno estado de sítio, quando, em 20 de abril de 1911, o Governo Federal deixou de cumprir uma decisão deste Tribunal, concedendo habeas corpus aos membros do Conselho Municipal" (CORREIO DA MANHÃ, 18 de janeiro de 1923, p. 1). O ministro Alfredo Pinto leu na sessão sua moção-protesto, apresentado como Presidente do Instituto Brasileiro de Advogados naquela oportunidade. Na moção, havia várias críticas ao Poder Executivo, afirmando que o Poder Judiciário seria a autoridade suprema na interpretação da Constituição e na interpretação das leis e que o descumprimento do julgado do mais elevado tribunal de justiça do País repugnava a consciência jurídica da Nação. Por fim, dizia que mantinha a mesma posição expressada em 1911.

Após as declarações de repúdio ao Decreto 15922 pelos ministros Guimarães Natal e Hermenegildo de Barros, o ministro Edmundo Lins, que votara contra a concessão de habeas corpus a Raul Fernandes, pronunciou-se também contra a ideia do protesto. Para ele, apenas o Congresso Nacional poderia julgar os atos do Presidente da República, caso este incorresse em algum crime de responsabilidade ${ }^{35}$. Assim sendo, recomendou o envio do processo ao Procurador-Geral da República para que fossem tomadas as providências cabíveis ${ }^{36}$.

Presidente do mesmo Estado, em virtude do acórdão do Supremo Tribunal Federal. Este considera inexistente o decreto de intervenção, não aceita as explicações de haver sido cumprido o habeas corpus, explicações irrisórias, ofensivas ao bom senso de qualquer pessoa, principalmente do Supremo Tribunal, cujo prestígio se pretendeu enfraquecer, mas que tem sido e sempre será a garantia suprema dos direitos individuais contra o arbítrio e a prepotência" (ibid., loc. cit.).

${ }^{34}$ Alfredo Pinto Vieira de Mello nasceu em Pernambuco e se formou pela Faculdade de Direito do Recife. Entre 1906 e 1909 exerceu o cargo de chefe de polícia do Distrito Federal. Foi eleito Presidente do Instituto da Ordem dos Advogados Brasileiros de 1910 a 1913, tendo feito parte, no governo de Nilo Peçanha, da Comissão de juristas encarregada de elaborar o projeto do Código de Processo Civil, Comercial e Penal do Distrito Federal. Disponível em: <http://www.stf.jus.br/portal/ministro/verMinistro.asp?periodo=stf\&id=197>. Acesso em: 22 dez. 2013.

${ }^{35}$ Trecho do voto de Edmundo Lins: "Efetivamente, dias depois da concessão do habeas corpus foi publicado o decreto n. 15922, de 10 de janeiro de 1923, que decretou a intervenção do Governo Federal no Estado do Rio. Fazendo-o, procedeu bem o Exmo. Sr. Presidente da república ou procedeu mal? Falece-me por completo competência para decidi-lo, pois do ato de S. Ex. só é juiz o Congresso Nacional" (CORREIO DA MANHÃ̂, 18 de janeiro de 1923, p. 1).

36 “'́́, pois, meu voto a rejeição dos protestos e, como admiti, a bem da argumentação, que tenha havido abuso de autoridade por parte do Exmo. Sr. Presidente da república, mandar se remetam o ofício do Sr. Dr. Raul Fernandes e os documentos que o instruem ao Exmo. Sr. Ministro Procurador-Geral da República para que se digne proceder como lhe parecer de direito" (ibid., loc. cit.).

Revista da Faculdade de Direito - UFPR, Curitiba, vol. 60, n. 1, jan./abr. 2015, p. 61-84. 
O ministro Pedro dos Santos, que havia votado contra a concessão do habeas corpus por ser questão política, reconheceu que o acórdão deveria ter sido cumprido ${ }^{37}$, chamando atenção para a obrigatoriedade do cumprimento das decisões do Judiciário. Não obstante, o ministro subscreveu a proposta de Edmundo Lins por entender que o papel do Judiciário não seria elaborar moções: “ante esta situação, o que cumpre ao Tribunal não é votar moções, mais ou menos fervidas ou veementes, em absoluto impróprias de uma corporação judiciária, mas agir com a lei e dentro da lei [...]" (CORREIO DA MANHÃ, 18 de janeiro de 1923, p. 1). Ao mesmo tempo que Pedro dos Santos defendia a devida execução do acórdão por parte do Poder Executivo, argumentava que a opção de exigir isso por meio de uma moção seria ignorar os instrumentos disponíveis ao Judiciário para fazê-lo.

O Procurador-Geral da República também reforçou essa posição ao afirmar que "os tribunais proferem sentenças para serem executadas; não votam protestos ou moções. Não esqueçamos de que somos um Tribunal judiciário, sem iniciativa, como é da índole e da essência do Poder Judiciário" (JORNAL DO COMMERCIO, 18 de janeiro de 1923, p. 1).

Essas são as únicas informações da sessão secreta contida em ata $^{38}$. O Correio da Manhã ainda destacava a tensão presente na sessão secreta ${ }^{39}$. Os jornais O Paiz e Jornal do Commercio, mais governistas, relataram a respeito da sessão secreta que o protesto de Guimarães Natal fora rejeitado por oito votos a cinco $^{40}$. Os jornais $O$ Jornal e Correio da

\footnotetext{
37 "Assim, bem ou mal, a ordem foi concedida, um acórdão do Supremo Tribunal a autorizou. Esse julgado, portanto, devia ser obedecido. Pouco importa que nele se possa abrigar uma usurpação de funções próprias do Congresso Nacional. No sistema político que nos rege, ao menos nominalmente, os acórdãos inconstitucionais não firmam jurisprudência, não podem ser invocados como fundamento de decidir para casos futuros, mas, no caso especial sobre o qual o Tribunal se manifestou, a decisão é soberana e tão obrigatória é para as partes interessadas como para os outros Poderes" (ibid., loc. cit.).

${ }^{38}$ No O JORNAL do dia 21 de janeiro de 1923 há uma publicação que indica que o redator da ata da sessão secreta do dia 13 de janeiro foi o Procurador-Geral Pires e Albuquerque. A ata publicada, não obstante, tinha outro conteúdo. Pires e Albuquerque, inconformado, pronuncia-se em sessão do dia 20 de janeiro da seguinte forma: "Quero apenas declarar que não tenho parte na criação deste novo modelo de atas, que isto não constava das notas que entreguei ao secretário, depois de lidas a todos os juízes; que eu não escreveria isto, porque: (i) Não é verdade que se tivesse 'censurado com veemência' qualquer procedimento do sempre acatado e digno Presidente, ainda há dias confirmado no alto posto que vem honrando há longos anos, por quase unanimidade; (ii) Quando tivesse ocorrido o que aí infielmente se narra, a deliberação do Tribunal vedava que se desse à publicidade; (iii) Não é curial que nas atas dos trabalhos do Tribunal se permita o secretário qualificar os atos dos ministros e as discussões que entre eles se travam, adjetivando-as de modo tão inconveniente e desrespeitoso". A partir desse pronunciamento de Pires e Albuquerque é possível lançar duas hipóteses. Primeiramente, a partir do ponto (ii), é possível inferir que Pires e Albuquerque, ao relatar a sessão secreta, tenha omitido importantes debates e discussões mais acaloradas. Em segundo lugar, a interferência dos secretários nas atas e publicações do STF é algo que se nota em alguns episódios do Tribunal ao longo da Primeira República. É possível especular a respeito da conexão política desses funcionários.

39 "A sessão secreta do Tribunal durou até quase 3 horas da tarde. Enquanto lá dentro ela se realizava, nada transpirava cá fora. Apenas tinha-se uma vaga impressão de que as coisas iam correndo mais animadas, pois todos os Ministros não só usaram da palavra, como se apartearam com azedume" (CORREIO DA MANHẪ de 14 de janeiro de 1923 , p. 3).

${ }^{40}$ JORNAL DO COMMERCIO e O PAIZ de 14 de janeiro de 1923. De acordo com O PAIZ, votaram a favor do protesto os ministros Guimarães Natal (autor da proposta), Pedro Mibielli, Hermenegildo de Barros, Leoni Revista da Faculdade de Direito - UFPR, Curitiba, vol. 60, n. 1, jan./abr. 2015, p. 61-84.
} 
Manh $\tilde{a}^{41}$ destacavam que dos oito votos contra a proposta, dois eram questionáveis, uma vez que o Presidente do STF e o Procurador-Geral supostamente não deveriam votar a respeito da questão, e que Edmundo Lins e Pedro dos Santos, mesmo tendo votado contra o protesto, reforçavam a versão de que o Poder Executivo descumprira o acórdão.

\subsection{SESSÃO DE 17 DE JANEIRO E A NOVA PROPOSTA DE PROTESTO DE HERMENEGILDO DE BARROS}

O debate, então, foi retomado na sessão seguinte, do dia 17 de janeiro, a partir da leitura e aprovação da ata do dia 13 de janeiro. O ministro Hermenegildo de Barros mudou a estratégia e buscou criar um canal de diálogo com o Poder Executivo, ao reconhecer a disposição do Poder Executivo de evitar um conflito desnecessário com o Judiciário ${ }^{42}$. Ele lançou, então, uma indicação de que o STF representasse ao Executivo, para que este reconhecesse o erro e admitisse o descumprimento do habeas corpus. A indicação previa que, se o Poder Executivo desejasse manter boas relações com o Judiciário, deveria reconsiderar a expedição do Decreto $15922^{43}$.

A indicação do ministro Hermenegildo de Barros recebeu apenas quatro votos favoráveis: do próprio Hermenegildo de Barros e de Pedro Mibielli, Leoni Ramos e Guimarães $\mathrm{Natal}^{44}$. Daqueles que votaram contra a indicação, surgiram alguns posicionamentos interessantes sobre a relação que o Tribunal deveria estabelecer com o Poder Executivo.

Ramos e Alfredo Pinto. Contra, teriam votado os ministros Hermínio do Espírito Santo, Viveiros de Castro, Geminiano da Franca, Godofredo Cunha, André Cavalcanti, Pedro dos Santos, Edmundo Lins e o ProcuradorGeral Pires e Albuquerque. É possível observar que André Cavalcanti, que tinha votado a favor da concessão do habeas corpus 8800 , foi contra a publicação do protesto. Como demonstrado na nota de rodapé 12 , o ministro Cavalcanti não tinha posicionamento político claro naquele momento e pode ter sido convencido por seus pares ou por agentes de fora do Tribunal a não fortalecer a ideia da publicação do protesto.

${ }^{41}$ O JORNAL de 14 de janeiro de 1923; CORREIO DA MANHÃ de 14 de janeiro de 1923, p. 3.

42 "O Poder Executivo reafirma com tanta insistência o propósito em que se acha de manter boas relações com o Poder Judiciário, que é possível a alguém admitir um equívoco de sua parte, quando declara estar cumprido o habeas corpus. Se se provar, porém, o contrário, de acordo com as próprias palavras do presidente da República, parece que S. Ex. se convencerá do engano, que corrigirá, e assim desaparecerão as nuvens que estão ameaçando tempestades entre os dois poderes" (CORREIO DA MANHÃ, 18 de janeiro de 1923, p. 1).

43،'Se o Poder Executivo reconsiderar o seu ato, tollitur quaestio. Se o não fizer, estará o acórdão desacatado, mas com isso nada perderá o prestígio do Tribunal, que será tanto maior quanto, para repetir palavras de outrem, 'mais atrevida for a insolência oficial, que lhe desobedecer'" (ibid., loc. cit.).

${ }^{44}$ De acordo com o Jornal do Commercio (18 de janeiro de 1923) e com O PAIZ (18 de janeiro de 1923, p. 6), Guimarães Natal votou a favor da indicação. Já o Correio da Manhã (18 de janeiro de 1923) afirmou que Guimarães Natal, mesmo reforçando a certeza de que o acórdão do STF fora descumprido, apontou a confusão da indicação elaborada por Hermenegildo de Barros e votou contra. O Jornal apenas relatou que a indicação de Hermenegildo de Barros foi rejeitada por maioria.

Revista da Faculdade de Direito - UFPR, Curitiba, vol. 60, n. 1, jan./abr. 2015, p. 61-84. 
O ministro Edmundo Lins disse que mantinha o posicionamento relativo ao protesto apresentado por Guimarães Natal, mas mudava sua opinião a respeito do descumprimento do acórdão. Para ele, o habeas corpus foi plenamente cumprido pelo Presidente da República (JORNAL DO COMMERCIO, 18 de janeiro de 1923). É possível que essa súbita mudança de opinião do ministro tenha sido influenciada pelo Ministro da Justiça, João Luiz Alves, ou até mesmo pelo Presidente da República ${ }^{45}$.

Alfredo Pinto, que havia votado a favor do protesto de Guimarães Natal, votou contra a indicação de Hermenegildo de Barros. Para ele, era preciso encerrar de uma vez por todas o incidente (CORREIO DA MANHÃ, 18 de janeiro de 1923, p. 1) e o "Tribunal não podia nem devia enviar representação ou apelos a qualquer dos outros poderes" (JORNAL DO COMMERCIO, 18 de janeiro de 1923). Sugeriu, então, discutir a legalidade do ato do governo quando o caso fosse apresentado ao STF pelas vias processuais cabíveis.

Viveiros de Castro defendeu que o STF não seria competente para analisar se o Presidente exorbitou ou não de suas funções (CORREIO DA MANHÃ, 18 de janeiro de 1923 , p. 1) ${ }^{46}$. Pedro dos Santos reafirmou seu posicionamento apresentado na sessão secreta (CORREIO DA MANHÃ, 18 de janeiro de 1923, p. 1). Godofredo Cunha apresentou opinião própria, expressa em acórdão de $1911^{47}$.

O ministro Geminiano da Franca votou contra a indicação e disse ter havido outros protestos no Tribunal sem que nenhum deles produzisse resultados eficientes (CORREIO DA MANHÃ, 18 de janeiro de 1923, p. 1). Aqui se percebe uma frustração do ministro diante do instrumento do protesto. $\mathrm{O}$ registro em ata de um desconforto do Tribunal perante o descumprimento de uma de suas decisões não era capaz de reverter a imposição da vontade do Poder Executivo.

\subsection{CONSIDERAÇÕES SOBRE O CASO DO HABEAS CORPUS 8800}

\footnotetext{
${ }^{45}$ Em carta de Carvalho Britto destinada a Arthur Bernardes, de 12 de junho de 1922 (BRITTO, 1922), o redator dizia que procurou Edmundo Lins para tratar do caso do habeas corpus e que "Edmundo já tem o voto feito e disse-me que não desonrará o Estado de Minas". A partir dessa carta é possível especular a respeito da conexão entre Edmundo Lins, nascido em Serro (MG), e os políticos mineiros.

${ }^{46}$ CORREIO DA MANHÃ, 18 de janeiro de 1923, p. 1 . No jornal O PAIZ (18 de janeiro de 1923, p. 6) afirmouse que o ministro Viveiros de Castro se pronunciara da seguinte forma: "não admite que se transforme o Supremo Tribunal em bandeira para amparar revoluções". Viveiros era um dos ministros do STF mais conservadores e ligados ao governismo.

${ }^{47}$ O JORNAL, 18 de janeiro de 1923; JORNAL DO COMMERCIO, 18 de janeiro de 1923. Trecho de sua opinião de 1911: "O poder excepcional do Governo, em matéria de intervenção, como em matéria de estado de sítio, exercido sob o exame imediato do Poder Legislativo, escapa à intromissão judicial”. De acordo com o jornal O PAIZ (18 de janeiro de 1923, p. 6), Leoni Ramos rebateu que o caso em questão e o caso de 1911 não teriam paridade.
}

Revista da Faculdade de Direito - UFPR, Curitiba, vol. 60, n. 1, jan./abr. 2015, p. 61-84. 
Guimarães Natal, o ministro relator do habeas corpus 8800, mencionou na sessão de 17 de janeiro de 1923 que outros protestos haviam sido elaborados por ministros do STF sem que se produzisse o efeito desejado. A crise de 1923 não havia sido o único momento em que o STF foi confrontado pela Presidência da República. Em 1898 Prudente de Morais redigiu mensagem ao Congresso Nacional com duras críticas à recente concessão de habeas corpus aos desterrados de Fernando de Noronha. Os ministros do STF Lúcio de Mendonça, Macedo Soares, Espírito Santo e Manuel Murtinho decidiram submeter à aprovação de seus colegas um protesto contra a mensagem presidencial (RODRIGUES, 1968, p. 124). O então Presidente do Tribunal argumentou que o STF não deveria se pronunciar, por moções e protestos, sem apoio nas disposições do regimento. Colocada a proposta em votação, ela foi rejeitada por seis votos a quatro. João Barbalho disse ter votado contra a proposta por entender que "O tribunal desce de sua dignidade, ocupando-se de acusação tão indigna e soez, como aquela de que se trata" (BARBALHO apud RODRIGUES, 1968, p. 127). A reação da imprensa governista contra essa tentativa de publicação de moção de repúdio foi intensa. Não obstante, o Tribunal tomou decisão contra os interesses do governo e galgou maior poder no jogo da política por ter firmado essa decisão.

Uma nota de repúdio foi aprovada por unanimidade em 1897 e publicada em ata. Tratava-se de uma manifestação contra edição de lei orçamentária, tida como inconstitucional, que diminuía os vencimentos dos juízes federais (RODRIGUES, 1968, pp. 137-9). A questão do vencimento dos magistrados parece ter sido a única que uniu o Tribunal, resultando na edição de um protesto contra a ação do Poder Executivo.

Algumas considerações podem ser traçadas sobre os conflito entre o STF e a Presidência da República, em especial no que se refere ao descumprimento da decisão do habeas corpus 8800. Em primeiro lugar, é visível, por um lado, a ação autoritária de Arthur Bernardes ao lançar o decreto de intervenção federal no Estado do Rio de Janeiro. Por outro lado, é também perceptível o esforço político de Bernardes e de seus aliados para evitar ao máximo o prosseguimento dessa crise. O Poder Executivo não podia simplesmente descumprir a decisão do STF, era preciso estabelecer uma negociação a fim de garantir maior legitimidade a seus atos. Essa movimentação, por mais que fosse apenas pro forma, era fundamental para garantir o mínimo de legitimidade às instituições envolvidas.

O STF tinha como sua principal arma de independência o julgamento de habeas corpus políticos contra a vontade do Executivo, mas sempre corria o risco de ter sua decisão ignorada. Ficava, de certo modo, colocando à prova sua capacidade institucional, principalmente por ser instituição nova, frágil e de pouco prestígio. Os momentos em que o 
Tribunal se posicionou com mais firmeza contra os interesses do governo foram importantes para que o STF construísse uma imagem como poder mais autônomo e não como apenas um braço da presidência da República.

$\mathrm{Na}$ tarefa de tornar o Tribunal mais independente, não caía bem aceitar com resignação o descumprimento de uma de suas decisões por parte do Executivo. Por isso há todo o jogo de cena, por meio dos "protestos" e das "moções de repúdio", para o Tribunal tentar firmar com mais veemência sua autoridade. Mesmo ministros mais governistas às vezes faziam coro às reclamações contra o autoritarismo do governo e o descumprimento das decisões.

No caso do habeas corpus 8800 , ao que parece, o jogo de convencimento foi realizado diretamente pelo Presidente do Tribunal. O então presidente Hermínio do Espírito Santo estabeleceu a interlocução entre os Poderes Judiciário e Executivo, de modo a resguardar a imagem de ambos.

Guimarães Natal, o relator do processo e que posteriormente esboçou a nota de repúdio, era naquele ano o segundo ministro mais antigo e deveria ter sido eleito vicepresidente do Tribunal, segundo a praxe então vigente. No entanto, quem obteve a maioria dos votos foi o ministro Godofredo Cunha. Em 1927, na eleição para Presidente do STF, foi também eleito o ministro Godofredo Cunha, o que fez Guimarães Natal requerer sua aposentadoria (RODRIGUES, 1968, p. 214). Ao que parece, a posição mais radical de Guimarães Natal não convinha ao papel apaziguador que vinha sendo exercido pelos presidentes do STF. Por mais que o STF tenha enfrentado em alguns momentos os interesses dos outros Poderes, na maioria das vezes contornou esses conflitos fazendo arranjos ou se resignando diante do descumprimento de suas decisões.

\section{FONTES E REFERÊNCIAS}

AINDA a intervenção no estado do Rio. O Jornal, Rio de Janeiro, 18 jan. 1923.

A INTERVENÇÃO federal no estado do Rio - ainda o caso do habeas corpus. O Jornal, Rio de Janeiro, 21 jan. 1923.

ALVES, João Luiz. Carta do então secretário de finanças do governo de Minas Gerais a Arthur Bernardes. Universidade Estadual de Campinas (Unicamp). Instituto de Filosofia e Ciências Humanas. Arquivo Edgard Leuenroth - Fundo Arthur Bernardes. Rolo 29. 24 jun. 1922. 
BERNARDES, Arthur; ROUSSOULIÈRES, Leon. Cartas trocadas entre os autores nos anos de 1921 e 1922. Universidade Estadual de Campinas (Unicamp). Instituto de Filosofia e Ciências Humanas. Arquivo Edgard Leuenroth - Fundo Arthur Bernardes. Rolos 24, 29, 30 e 31. 1921-2.

BRASIL. Congresso. Câmara dos deputados. Intervenção do Estado do Rio (1992-1923). Série Documentos Parlamentares. $16^{\circ}$ volume. Rio de Janeiro: Typ. de Jornal do Commercio, de Rodrigues \& C, 1923.

Decreto $\mathrm{n}^{\mathrm{o}}$ 15922, de 10 de janeiro de 1923. Decreta a intervenção do Governo Federal no Estado do Rio de Janeiro. Diário Oficial da União. Seção 1, p. 1292. Rio de Janeiro, 11 jan. 1923. Disponível em: <http://www2.camara.leg.br/legin/fed/decret/19201929/decreto-15922-10-janeiro-1923-510462-publicacaooriginal-1-pe.html>. Acesso em: 22 dez. 2013.

Supremo Tribunal Federal. Histórico das composições do Supremo Tribunal Federal na República - Ministro Alfredo Pinto Vieira de Mello. Disponível em: $<$ http://www.stf.jus.br/portal/ministro/verMinistro.asp?periodo=stf\&id=197>. Acesso em: 22 dez. 2013.

BRITTO, Carvalho. Carta destinada a Arthur Bernardes. Universidade Estadual de Campinas (Unicamp). Instituto de Filosofia e Ciências Humanas. Arquivo Edgard Leuenroth - Fundo Arthur Bernardes. Rolo 29. 12 jun. 1922.

COSTA, Emilia Viotti da. O Supremo Tribunal Federal e a construção da cidadania. 2a edição. São Paulo: Ieje, 2007.

FERREIRA, Marieta de Moraes. Crime e castigo. In: A República na velha província. Marieta de Moraes Ferreira (Org.). Rio de Janeiro: Rio Fundo Ed., 1989.

KOERNER. Andrei. Judiciário e cidadania na Constituição da República Brasileira (18411920). 2a edição. Curitiba: Juruá, 2010.

NO SUPREMO Tribunal Federal. Jornal do Commercio, Rio de Janeiro, 14 jan. 1923.

O CASO do estado do Rio - depois de ouvir as informações do Ministro da Justiça, o Supremo Tribunal resolve em sessão secreta. Correio da Manhã, Rio de Janeiro, p. 3, 14 jan. 1923.

O CASO do estado do Rio no Supremo Tribunal Federal. Jornal do Commercio, Rio de Janeiro, p. 1, 18 jan. 1923.

O CASO do estado do Rio. O Paiz, Rio de Janeiro, p. 5-6, 14 jan. 1923.

O CASO do estado do Rio. O Paiz, Rio de Janeiro, p. 6, 18 jan. 1923.

O CASO do estado do Rio - o que foi a sessão secreta do Supremo Tribunal. Correio da Manhã, Rio de Janeiro, p. 1, 18 jan. 1923. 
OFFICIO do juiz seccional ao Ministro Espírito Santo. O Jornal, Rio de Janeiro, 11 jan. 1923.

OFFICIO do Presidente do Supremo Tribunal Federal ao juiz federal em Nitherohy. O Jornal, Rio de Janeiro, 11 jan. 1923.

OS SUCESSOS no estado do Rio - A intervenção e o habeas corpus. O Jornal, Rio de Janeiro, 14 jan. 1923.

RECLAMAÇÃO do Sr. Raul Fernandes. O Jornal, Rio de Janeiro, 11 jan. 1923.

REPOLÊS, Maria Fernanda Salcedo. A identidade do sujeito constitucional e controle de constitucionalidade - raízes históricas da atuação do Supremo Tribunal Federal. Rio de Janeiro: edições Casa de Rui Barbosa, 2010.

A identidade do sujeito constitucional no Brasil: uma visita aos seus pressupostos histórico-teoréticos na passagem do Império para a República, da perspectiva da forma de atuação do guardião máximo da Constituição. In: XVI Encontro Preparatório do Conpedi, 2007, Campos dos Goytacazes - RJ. Anais Conpedi / Campos dos Goytacazes, 2007.

RIBEIRO, Gladys Sabina. Cidadania e luta por direitos na Primeira República: analisando processos da Justiça Federal e do Supremo Tribunal Federal. Revista Tempo. Revista do Departamento de História da UFF, v. 22, p. 101-17, 2009.

RODRIGUES, Lêda Boechat. A Corte Suprema e o direito constitucional americano. Rio de Janeiro: Editora Forense, 1958.

História do Supremo Tribunal Federal. Tomo I. 1891-1898 - defesa das liberdades civis. Rio de Janeiro: Editora Civilização Brasileira, 1965.

História do Supremo Tribunal Federal. Tomo II. 1899-1910 - defesa do federalismo. Rio de Janeiro: Editora Civilização Brasileira, 1968.

. História do Supremo Tribunal Federal. Tomo III. 1910-1926 - doutrina brasileira do habeas corpus. Rio de Janeiro: Editora Civilização Brasileira, 1991.

. História do Supremo Tribunal Federal. Tomo IV - volume I. 1930-1963. Rio de Janeiro: Editora Civilização Brasileira, 2002.

ROSENFELD, Michel. A identidade do sujeito constitucional. Tradução de: Menelick de Carvalho Netto. Belo Horizonte: Mandamentos, 2003.

UMA INDICAÇÃO do Ministro Hermenegildo. Correio da Manhã, Rio de Janeiro, p. 1, 18 jan. 1923.

PROTESTS BY THE SUPREME COURT DURING THE FIRST REPUBLIC - THE TRIAL OF HABEAS CORPUS 8800 AND THE CONFLICT BETWEEN EXECUTIVE AND JUDICIARY POWERS 
ABSTRACT: This research investigates the role of the Brazilian Supreme Federal Court (Supremo Tribunal Federal - STF) during the First Republic (1889-1930) from an institutional perspective, focusing especially on the conflictual relationship between the executive power and the judiciary one. It describes some episodes involving the so-called issue of protests in which that Court expressed its resentment through a public statement against the actions of the executive branch. From the detailed analysis of one of these episodes, occurred in 1923, it will be possible to demonstrate the competition for power between the Supreme Court and the Presidency.

KEYWORDS: Brazilian Supreme Federal Court. First Republic. Protest.

Recebido: 20 de maio de 2014

Aprovado: 28 de julho de 2014 